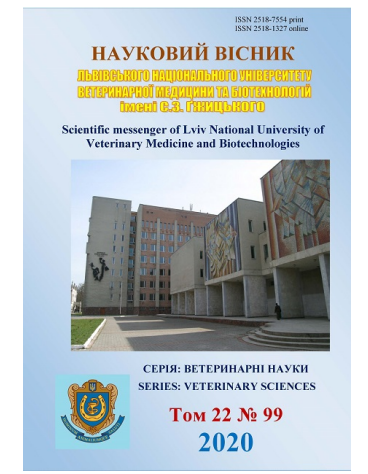

\author{
Науковий вісник Дьвівського національного університету \\ ветеринарної медицини та біотехнологій імені С.3. Гжицького. \\ Серія: Ветеринарні науки \\ Scientific Messenger of Lviv National University \\ of Veterinary Medicine and Biotechnologies. \\ Series: Veterinary sciences
}

\title{
Sanitary and hygienic condition of refrigerators and facilities for storage of meat of slaughtered animals at the powers of their production and circulation
}

\author{
N. M. Bogatko \\ Bilotserkivsky National Agrarian University, Bila Tserkva, Ukraine
}

Article info

Received 27.08.2020

Received in revised form 24.09.2020

Accepted 25.09.2020

Bilotserkivsky National Agrarian University, Cathedral Square, 8/1, Bila Tserkva, Kyiv region, 09117, Ukraine.

Tel.: +38-067-395-21-50 E-mail:nadiyabogatko@ukr.net
Bogatko, N. M. (2020). Sanitary and hygienic condition of refrigerators and facilities for storage of meat of slaughtered animals at the powers of their production and circulation. Scientific Messenger of Lviv National University of Veterinary Medicine and Biotechnologies. Series: Veterinary sciences, 22(99), 8-19. doi: 10.32718/nvlvet9902

The sanitary and hygienic condition of refrigeration chambers (air, walls, floors, tables/counters, refrigeration chamber hangers) in the process of production and storage of meat of slaughter animals (beef, pork, lamb and goat) at a temperature from $4 \pm 2{ }^{\circ} \mathrm{C}$ to $-12{ }^{\circ} \mathrm{C}$. Indicators of qualitative and quantitative composition of air microflora of refrigerators of meat processing capacity, wholesale base at a temperature of $-2 \ldots-3{ }^{\circ} \mathrm{C}$ for 20 days, at a temperature of $-12{ }^{\circ} \mathrm{C}$, where beef for 8 months, pork for 3 months, lamb and goat for 6 months; refrigerators, supermarket counters at a temperature of $4 \pm 2{ }^{\circ} \mathrm{C}$ for 2 days and at a temperature of $-6 \ldots-8{ }^{\circ} \mathrm{C}$ for 20 days, where the meat of slaughter animals was sold; agri-food market at a sales temperature of $0 \ldots 6{ }^{\circ} \mathrm{C}$ and 2 days and at a temperature of $0 \ldots-1{ }^{\circ} \mathrm{C}$ for 16 days, where the meat of slaughter animals was stored for sale. It is proved that at a temperature of $-12{ }^{\circ} \mathrm{C}$ in refrigeration chambers during storage of meat of slaughter animals at production facilities and wholesale base at relative humidity of 95 and $90 \%$ for 3, 6 and 8 months, respectively, the content of MAFANM in the air was respectively $(0.39 \pm 0.04) \times 10^{2}$ and $(0.41 \pm 0.04) \times 10^{2} \mathrm{CFU} / \mathrm{m}^{3}$; at a temperature of $-2 \ldots-3{ }^{\circ} \mathrm{C}$ in refrigeration chambers of power and wholesale base at a relative humidity of $90 \%$ for 20 days, respectively $-(0.52 \pm 0.05) \times 10^{2}(P \leq 0.05)$ and $(1.19 \pm 0.09) \times 10^{2} \mathrm{CFU} / \mathrm{m}^{3}(P \leq 0.001)$; at a temperature of $-6 \ldots-8{ }^{\circ} \mathrm{C}$ in the refrigerator at a relative humidity of $85 \%$ of the supermarket for 20 days $(0.61 \pm 0.06) \times 10^{2} \mathrm{CFU} / \mathrm{m}^{3}$, and at a temperature of $4 \pm 2{ }^{\circ} \mathrm{C}$ in an open refrigerator at a relative humidity $82 \%$ for 2 days $-(1.72 \pm 0.08) \times 10^{2} \mathrm{CFU} / \mathrm{m}^{3}(\mathrm{P} \leq 0.001)$; at a temperature of $0 \ldots 6^{\circ} \mathrm{C}$ in the refrigerating chamber of the premises on the agri-food market at a relative humidity of $88 \%$ and 2 days $-(2.19 \pm 0.11) \times 10^{2} \mathrm{CFU} / \mathrm{m}^{3}$, and at a temperature of $0 \ldots-1{ }^{\circ} \mathrm{C}$ for 16 days $-(1.89 \pm 0.09) \times 10^{2} \mathrm{CFU} / \mathrm{m}^{3}(P \leq 0.05)$. The probable dependence of the number of microorganisms on the air temperature of refrigeration chambers was determined: the lower the air temperature $\left(-12{ }^{\circ} \mathrm{C},-6 \ldots-8{ }^{\circ} \mathrm{C}\right)$, the higher the sanitary condition of the chambers. With increasing temperature in refrigeration chambers: $4 \pm 2{ }^{\circ} \mathrm{C}, 0 \ldots 6^{\circ} \mathrm{C}$ and $0 \ldots-1{ }^{\circ} \mathrm{C}$, the average number of mold fungi in the air increased in direct proportion: $65.00 \pm 1.04 \mathrm{CFU} / \mathrm{m}^{3}, 103.00 \pm 2.24 \mathrm{CFU} / \mathrm{m}^{3}$ (including $5 \pm 1$ Cladosporium herbarum, indicating its unsatisfactory sanitary condition) and $85.00 \pm 1.13(P \leq 0.001) \mathrm{CFU} / \mathrm{m}^{3}$. At a temperature of $-2 \ldots-3{ }^{\circ} \mathrm{C}$ in the refrigeration chamber of the slaughterhouse meat production capacity, the highest content of MAFANM was in the floor washes 4.48 times $(P \leq 0.001)$, in the walls -2.27 times $(P \leq 0.001)$ and hung -1.16 times $(P \leq 0.001)$ compared to the indicators in the refrigerator at a temperature of $-12{ }^{\circ} \mathrm{C}$. Using a temperature of $4 \pm 2{ }^{\circ} \mathrm{C}$ in a refrigerated open window in a supermarket, the highest content of MAFANM of high probability $(P \leq 0.001)$ was established from the washing of objects and hands of workers within $(8.23 \pm 0.11) \times 10^{1}-(1,83 \pm 0.06) \times 10^{2}$ $\mathrm{CFU} / \mathrm{cm}^{2}$; from the objects of agro-food market premises and hands of workers at a temperature of $0 \ldots 6^{\circ} \mathrm{C}$ was in the range $(1.08 \pm 0.07) \times 10^{2}-(2.24 \pm 0.14) \times 10^{2} \mathrm{CFU} / \mathrm{cm}^{2}$, which indicated their unsatisfactory sanitary condition. When using the temperature of $-12{ }^{\circ} \mathrm{C}$ in the refrigeration chambers of the meat production and wholesale base, the content of MAFANM from the washes of the objects was in the range: $(0.73 \pm 0.04) \times 10-(1.23 \pm$ $0,07) \times 10 \mathrm{CFU} / \mathrm{cm}^{2}$ and $(0.65 \pm 0.04) \times 10-(1.42 \pm 0.10) \times 10 \mathrm{CFU} / \mathrm{cm}^{2}$ (good sanitation); for temperatures $2 \ldots-3{ }^{\circ} \mathrm{C}-(0.85 \pm 0.05) \times 10-(5.51 \pm 0.11) \times 10 \mathrm{CFU} / \mathrm{cm}^{2}$ and $\left.(0.79 \pm 0.05) \times 10-5.29 \pm 0.12\right) \times 10 \mathrm{CFU} / \mathrm{cm}^{2}$ (satisfactory sanitary condition). Test cultures of bacteria of different genera were isolated from the facilities of refrigeration chambers of production facilities and wholesale base at temperatures of $-12{ }^{\circ} \mathrm{C}$ and $-2 \ldots-3{ }^{\circ} \mathrm{C}$ : Echerichia - 12.5-16.7\%; Staphylococcus aureus - up to $12.5 \%$, Salmonella - not detected; from the objects of refrigeration chambers of the agri-food market at room temperature $0 \ldots 6^{\circ} \mathrm{C}$ and $0 \ldots-1{ }^{\circ} \mathrm{C}$, knives, hands of workers: Echerichia - 41.7-50.0\%; Salmonella - 16.7-12.5\%; Staphylococcus aureus - up to 33.3-29.7\%; from supermarket facilities at the temperature of refrigeration chambers $-6 \ldots-8{ }^{\circ} \mathrm{C}$ and $4 \pm 2{ }^{\circ} \mathrm{C}$, knives, hands of 
employees: Echerichia - 16.7-50.0\%; Salmonella - 12.5-16.7\%; Staphylococcus aureus - 8.3-20.8\%. There was a directly proportional increase in the contamination of meat of slaughter animals MAFANM for storage and sale in refrigerators in the supermarket at a temperature of $4 \pm 2{ }^{\circ} \mathrm{C}$ and agri-food market at a temperature of $0 . .$. $6{ }^{\circ} \mathrm{C}$ for 2 days, respectively: in beef- $(1.15 \pm 0.22) \times 10^{3}$ and $(2.26 \pm 0.21) \times 10^{3} \mathrm{CFU} / \mathrm{cm}^{2}$; pork $-(1.32 \pm 0.18)$ $\times 10^{3}$ and $(2.81 \pm 0.19) \times 10^{3} \mathrm{CFU} / \mathrm{cm}^{2}$; mutton $-(1.09 \pm 0.20) \times 10^{3}$ and $(2.18 \pm 0.22) \times 10^{3} \mathrm{CFU} / \mathrm{cm}^{2}$; goat meat $-(1.18 \pm 0.12) \times 10^{3}$ and $(1.97 \pm 0.17) \times 10^{3} \mathrm{CFU} / \mathrm{cm}^{2}$. Hygienic criteria of the technological process in the meat of slaughter animals were the number of colonies of aerobic microorganisms in the meat of slaughter animals from $m=3.6 \log C F U / \mathrm{cm}^{2}$ to $m=3.9 \log C F U / \mathrm{cm}^{2}$ and from $M=5.1 \mathrm{CFU} / \mathrm{cm}^{2}$ up to $M=5.5 \mathrm{CFU} / \mathrm{cm}^{2}$ (in supermarkets) and from $m=3.7 \log C F U / \mathrm{cm}^{2}$ to $\mathrm{m}=4.4 \log C F U / \mathrm{cm}^{2}$ and from $M=5.1 \mathrm{CFU} / \mathrm{cm}^{2}$ to $M=5.4$ $C F U / \mathrm{cm}^{2}$ (in agri-food markets); Enterobacteriaceae in meat of slaughter animals from $m=1.6 \log C F U / \mathrm{cm}^{2}$ to $m=2.0 \log C F U / \mathrm{cm}^{2}$ and from $M=2.5 \mathrm{CFU} / \mathrm{cm}^{2}$ to $M=3.4 \mathrm{CFU} / \mathrm{cm}^{2}$ (in supermarkets) and from $\mathrm{m}=1.5 \mathrm{log}$ $C F U / \mathrm{cm}^{2}$ to $\mathrm{m}=2.3 \log \mathrm{CFU} / \mathrm{cm}^{2}$ and from $M=3.3 \mathrm{CFU} / \mathrm{cm}^{2}$ to $M=3.7 \mathrm{CFU} / \mathrm{cm}^{2}$ (in agri-food markets). Therefore, food market operators implementing the HACCP system based on the current procedures of GMP, GHP and GLP must carry out sanitary and microbiological control of refrigeration facilities (air, floors, tables/counters, walls, hangers) of meat production facilities, wholesale bases, supermarkets and agri-food markets, as well as knives and hands of workers, which will create appropriate sanitary and hygienic conditions at these facilities, prevent contamination of meat of slaughter animals with microorganisms, its spoilage, the emergence of food poisoning.

Key words: production and circulation facilities, facilities of refrigeration chambers, temperature, sanitary and hygienic condition, washes, meat of slaughter animals.

\title{
Санітарно-гігієнічний стан холодильних камер та об'єктів за зберігання м'яса забійних тварин на потужностях з їх виробництва та обігу
}

\author{
Н. М. Богатко \\ Білочерківський національний аграрний університет, м. Біла Церква, Украӥна
}

\begin{abstract}
Досліджено санітарно-гігієнічний стан холодильних камер (повітря, стін, підлоги, столів/прилавків, вішал холодильних камер) у проиесі виробництва та зберігання м'яса забійних тварин (яловичина, свинина, баранина і козлятина) за температури від $4 \pm 2{ }^{\circ} \mathrm{C}$ до -12 ${ }^{\circ} \mathrm{C}$. Встановлено показники якісного та кількісного складу мікрофлори повітря холодильних камер м'ясопереробної потужності, оптовоі бази за температури $-2 \ldots-3{ }^{\circ} \mathrm{C}$ на 20 добу, за температури $-12{ }^{\circ} \mathrm{C}$, де зберігались яловичина на 8 міс., свинина на 3 міс., баранина $і$ козлятина на 6 міс.; холодильних камер, прилавків супермаркету за температури $4 \pm 2{ }^{\circ} \mathrm{C}$ на 2 добу та за температури -6...-8 ${ }^{\circ} \mathrm{C}$ на 20 добу, де реалізовувалось м'ясо забійних тварин; агропродовольчому ринку за температури реалізаиії $0 \ldots 6{ }^{\circ} \mathrm{C}$ на 2 добу та за температури 0...$1{ }^{\circ} \mathrm{C}$ на 16 добу, де зберігалось м'ясо забійних тварин для реалізаиії. Доведено, щэо за температури -12 ${ }^{\circ} \mathrm{C}$ у холодильних камерах при зберіганні м'яса забійних тварин на потужності з виробництва та оптовій базі за відносної вологості відповідно 95 i 90 \% на 3, 6 i 8 міс. вміст МАФАнМ у повітрі становив відповідно $(0,39 \pm 0,04) \times 10^{2}$ ma $(0,41 \pm 0,04) \times 10^{2} \mathrm{KVO} / \mathrm{M}^{3}$; за температури $-2 \ldots-3{ }^{\circ} \mathrm{C}$ у холодильних камерах потужності та оптовій базі за відносної вологості $90 \%$ на 20 добу відповідно - $(0,52 \pm 0,05) \times 10^{2}(P \leq 0,05)$ та $(1,19 \pm$ $0,09) \times 10^{2} \mathrm{KУO} / \mathrm{M}^{3}(P \leq 0,001)$; за температури $-6 \ldots-8{ }^{\circ} \mathrm{C}$ у холодильній камері за відносної вологості $85 \%$ супермаркету на 20 добу $(0,61 \pm 0,06) \times 10^{2} \mathrm{KУO} / \mathrm{s}^{3}$, а за температури $4 \pm 2{ }^{\circ} \mathrm{C}$ у холодильній відкритій камері за відносної вологості $82 \%$ на 2 добу - $(1,72 \pm$ $0,08) \times 10^{2} \mathrm{KVO} / \mathrm{M}^{3}(P \leq 0,001)$; за температури $0 \ldots 6^{\circ} \mathrm{C}$ у холодильній камері приміщення на агропродовольчому ринку за відносної вологості $88 \%$ на 2 добу - $(2,19 \pm 0,11) \times 10^{2} \mathrm{KУO} / \mathrm{M}^{3}$, а за температури $0 \ldots-1{ }^{\circ} \mathrm{C}$ на 16 добу $-(1,8 \pm 0,09) \times 10^{2} \mathrm{KУO} / \mathrm{M}^{3}(\mathrm{P} \leq 0,05)$. Визначено вірогідну залежність кількості мікроорганізмів від температури повітря холодильних камер: чим нижча температура повітря (-12 ${ }^{\circ} \mathrm{C}$, $-6 \ldots$ $\left.-8{ }^{\circ} \mathrm{C}\right)$, тим вищий санітарний стан камер. $3 а$ збільшення температури у холодильних камерах: 4, $2{ }^{\circ} \mathrm{C}, 0 . \ldots 6{ }^{\circ} \mathrm{C}$ та $0 \ldots-1{ }^{\circ} \mathrm{C}$ прямо-

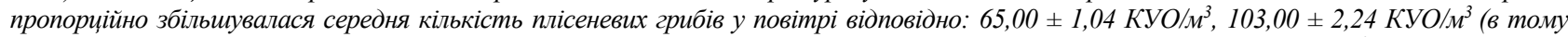

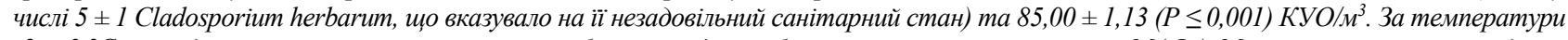
$-2 \ldots-3{ }^{\circ} \mathrm{C}$ у холодильній камері потужності з виробництва м'яса забійних тварин найвищий вміст МАФАнМ становив у змивах із підлоги - більше у 4,48 разу $(P \leq 0,001)$, стін - у 2,27 разу $(P \leq 0,001)$ та вішал - y 1,16 разу $(P \leq 0,001)$ порівняно з показникамим у холодильній камері за температури $-12{ }^{\circ} \mathrm{C}$. За використання температури $4 \pm 2{ }^{\circ} \mathrm{C}$ у холодильній відкритій вітрині в супермаркеті найбільший вміст МАФАнМ високого ступеня вірогідності $(P \leq 0,001)$ встановили зі змивів об' єктів та рук працівників в межах $(8,23 \pm 0,11) \times 10^{1}-(1,83 \pm$ $0,06) \times 10^{2} \mathrm{KУO} / \mathrm{cm}^{2}$; із об'єктів приміщень агропродовольчого ринку і рук прачівників за температури $0 . .66^{\circ} \mathrm{C}$ був 8 межах $(1,08 \pm$ $0,07) \times 10^{2}-(2,24 \pm 0,14) \times 10^{2} \mathrm{KУO} / \mathrm{cm}^{2}$, що вказувало на ӥхній незадовільний санітарний стан. За використання температури -12 ${ }^{\circ} \mathrm{C} y$ холодильних камерах потужності з виробництва м'яса та оптової бази вміст МАФАнМ зі змивів об'єктів становив відповідно в межах:

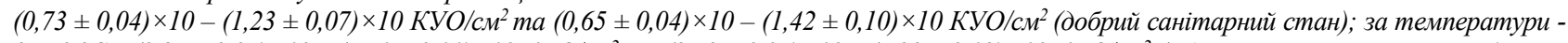

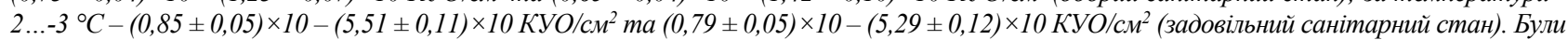
виділені тест-культури бактерій різних родів із об'єктів холодильних камер потужностей з виробництва та оптової бази за темпераmури $-12{ }^{\circ} \mathrm{C}$ ma -2...-3 ${ }^{\circ} \mathrm{C}$ : Echerichia - 12,5-16,7\%; Staphylococcus aureus - до 12,5\%, Salmonella - не виявлено; із об'єктів холодильних камер агропродовольчого ринку за температури приміщення $0 \ldots 6{ }^{\circ} \mathrm{C}$ та $0 \ldots-1{ }^{\circ} \mathrm{C}$, ножів, рук працівників: Echerichia - 41,7-50,0\%; Salmonella - 16,7-12,5\%; Staphylococcus aureus - до 33,3-29,7\%; із об'єктів супермаркету за температури холодильних камер -6...-8 ${ }^{\circ} \mathrm{C}$ та $4 \pm 2{ }^{\circ} \mathrm{C}$, ножів, рук прачівників: Echerichia - 16,7-50,0\%; Salmonella - 12,5-16,7\%; Staphylococcus aureus - 8,3-20,8\%. Відмічалося прямо пропориійне збільшення обсіменіння м'яса забійних тварин МАФАнМ за зберігання і реалізації в холодильних камерах у супермаркеті за температури $4 \pm 2{ }^{\circ} \mathrm{C}$ та агропродовольчому ринку за температури $0 . . .6{ }^{\circ} \mathrm{C}$ на 2 добу відповідно: в яловичині - (1,15 \pm $0,22) \times 10^{3} \mathrm{ma}(2,26 \pm 0,21) \times 10^{3} \mathrm{KУO} / \mathrm{cm}^{2} ;$ свинині $-(1,32 \pm 0,18) \times 10^{3} \mathrm{ma}(2,81 \pm 0,19) \times 10^{3} \mathrm{KVO} / \mathrm{cm}^{2} ;$ баранині $-(1,09 \pm 0,20) \times 10^{3} \mathrm{ma}(2,18 \pm$ $0,22) \times 10^{3} \mathrm{KУO} / \mathrm{cm}^{2}$; козлятині - $(1,18 \pm 0,12) \times 10^{3} \mathrm{ma}(1,97 \pm 0,17) \times 10^{3} \mathrm{KУO} / \mathrm{cm}^{2}$. Отже, оператори ринку харчових продуктів, впроваджуючи систему НАСCP на основі діючих процедур GMP, GHP та GLP, повинні здійснювати санітарно-мікробіологічний контроль об'єктів холодильних камер (повітря, підлоги, столів/прилавків, стін, вішал) потужностей з виробництва м'яса, оптових баз, супермакетів та агропродовольчих ринків, а також ножів і рук прачівників, що дасть можливість створити належні санітарно-гігієнічні умови на изи потужностях, запобігти обсіменінню м'яса забійних тварин мікроорганізмами, його псуванню, виникненню харчових токсикоінфек-
\end{abstract} uฺiŭ. 
Ключові слова: потужності з виробництва та обігу, об'єкти холодильних камер, температура, санітарно-гігієнічний стан, змиви, м'ясо забійних тварин.

\section{Вступ}

На операторів ринку покладено зобов'язання щодо виконання вимог дотримання законодавства під час виробництва та обігу екологічно безпечного м'яса забійних тварин - яловичини, свинини, баранини i козлятини. Згідно із Законом України "Про основні принципи та вимоги до безпечності та якості харчових продуктів" необхідно здійснювати інспекційні перевірки щодо дотримання санітарно-гігієнічних вимог за зберігання м'яса забійних тварин в холодильних камерах на потужностях з їх виробництва, оптових базах, супермаркетах і агропродовольчих ринках, а також виконувати вимоги нової Свропейської регламентації щодо харчових продуктів, Комісії Кодексу Аліментаріус, а також організовувати свою роботу на основі оцінки ризиків із санітарної безпеки харчових продуктів (Regulation EC № 178, 2002; Regulation EC № 852, 2004; Schillinger \& Lucke, 2003; Rodionova et al., 2020).

3 метою запобігання порушеннням санітарногігієнічного стану об'єктів холодильних камер потужностей 3 виробництва та обігу м'яса забійних тварин, ножів і рук працівників оператори ринку повинні здійснювати належний ризик-орієнтований контроль за мікробіологічними небезпеками (Listeria, S. aureus, мікроскопічні гриби) впродож виробництва (Odewade et al., 2018; Paliy et al., 2018), зберігання, реалізації яловичини, свинини, баранини і козлятини, що буде гарантувати високий рівень гігієни та харчової безпеки, ефективність функціонування системи управління ланцюгом поставок, зниження кількості аудиторських перевірок із боку державних установ та партнерів, зменшення випуску небезпечної м'ясної сировини (Velemets, 2020).

Визначення показників санітарномікробіологічного контролю холодильних камер, об'єктів на потужностях 3 виробництва та обігу є актуальним, тому що це запобігає негативному впливу на безпечність та якість м'яса забійних тварин в терміни закінчення його зберігання та відвертає нанесення шкоди здоров'ю пересічного споживача і дає можливість профілактувати харчові отруєння та харчові токсикоінфекції (Milios et al., 2012).

Мікробіологічний контроль на потужностях 3 виробництва і переробки м'яса проводиться при вимірюванні вмісту аденозитрифосфату (АТФ), що є енергоносієм і міститься в усіх живих клітинах бактерій і м'яса та на основі зіставлення визначеного об'єму АТФ до деякої кількості мікроорганізмів роблять висновок щодо їхнього кількісного складу (Nagibina et al., 2014). Оцінка мікробіологічної безпеки холодильних камер піддавалися візуальному огляду, рівням АТФ- біолюмісценції, індикаторних мікроорганізмів Escherichia coli i Staphylococcus aureus, а також наявності Listeria monocytogenes и Salmonella, які були виділені із полиць, відповідно у 17,9, 12,6, 59,5, 32,5 \% (Macias-Rodriguez et al., 2013).
За холодильного зберігання яловичини в ньому проходять мікробіологічні зміни через розмноження мезофільної та психротрофної мікрофлори, яку треба контролювати, внаслідок подальшого обсіменіння м’ясної сировини (Ercolini et al., 2009).

Для профілактики зниження ризику хвороб харчового походження була проведена перевірка холодильних камер методом ПЦР, яка показала, що 51,7 \% зразків були позитивні на патогени: L. monocytogenes 41,6\%, S. aureus 5,5\%, Salmonella spp. 4,6\%.

За дослідженнями (Bogatko \& Sakhniuk, 2013) було встановлено, що холодильні камери за температури $-1^{\circ} \mathrm{C}$ та $-12^{\circ} \mathrm{C}$ не чинять бактеріостатичного впливу на життєдіяльність плісеневих грибів, яких найбільше виявляли у повітрі на відстані від підлоги 0,5 м (7 \pm 2 колоній).

Дана тема $\epsilon$ досить актуальною під час впровадження системи НАССР на потужностях харчової галузі України, тому наші дослідження полягали у всебічному контролі санітарно-гігієнічного стану холодильних камер за різних температурних і вологісних режимів та інших об'єктів за зберігання та реалізації яловичини, свинини, баранини і козлятини в кінцевий нормативний термін зберігання на потужностях з їх виробництва та обігу.

Метою дослідження було встановити показники якісного та кількісного складу мікрофлори повітря, стін, підлоги, столів/прилавків, вішал холодильних камер, ножів, рук працівників за виробництва та обігу м'яса забійних тварин, а також встановити мікробіологічні показники за вмістом МАФАнМ в м'ясі забійних тварин, що зберігалися у холодильних камерах потужностей різних типів.

\section{Матеріал і методи досліджень}

Випробування щодо мікробіологічного контролю відбитків та змивів із об'єктів державного контролю проводили на потужностях з виробництва м'яса ТОВ МПЗ "Баварія", оптовій базі, супермаркеті “Сільпо", “АТБ”, агропродовольчому ринку Київської області згідно з вимогами національного стандарту ДСТУ ISO 18593:2006 “Мікробіологія харчових продуктів і кормів для тварин. Мікробіологічний аналіз із використанням відбитків і змивів 3 поверхонь". Відбирали проби з повітря холодильних камер: м'ясопереробної потужності, оптової бази за температури $-2 \ldots-3{ }^{\circ} \mathrm{C}$ на 20 добу, за температури $-12{ }^{\circ} \mathrm{C}$, де зберігались яловичина на 8 міс., свинина на 3 міс., баранина і козлятина на 6 міс.; із полиць холодильної відкритої вітрини за температури $4 \pm 2{ }^{\circ} \mathrm{C}$ на 2 добу та холодильних камер за температури $-6 \ldots-8{ }^{\circ} \mathrm{C}$ на 20 добу, де реалізовувалось м'ясо забійних тварин; агропродовольчому ринку за температури реалізації $0 \ldots 6^{\circ} \mathrm{C}$ на 2 добу та за температури $0 \ldots-1{ }^{\circ} \mathrm{C}$ на 16 добу, де зберігалося м'ясо забійних тварин для реалізації. Змиви також відбирали з об'єктів холодильних камер: стін, підлоги, вішал м'ясопереробної потужності й оптової бази, а також із 
рук працівників. У супермаркетах - зі столів, підлоги, стін, де проходила розрубка і пакування м'ясних туш яловичини, свинини, баранини і козлятини, із полиць холодильної відкритої вітрини та холодильних камер за температури $-6 \ldots-8{ }^{\circ} \mathrm{C}$, де реалізувалося м'ясо забійних тварин, із рук та ножів працівниківфасувальників м'яса; на агропродовольчому ринку зі столів, підлоги, ножів та рук продавців. Об'єм досліджуваної проби повітря $\left(\mathrm{M}^{3}\right)$ у холодильних камерах м'ясопереробної потужності складав $134,21 \times 10^{2} \mathrm{M}^{3}$; оптової бази - $114,50 \times 10^{2} \mathrm{~m}^{3}$; супермакеті $3,78 \times 10^{2} \mathrm{M}^{3}$, холодильній відкритій полиці супермаркету $1,20 \times 10 \mathrm{~m}^{3}$; холодильній камері агропродовольчого ринку $2,5 \times 10 \mathrm{~m}^{3}$, холодильному приміщенні реалізації м'яса $-8,24 \times 10^{2} \mathrm{M}^{3}$.

За проведення відбору повітря в холодильних камерах потужностей 3 виробництва та обігу м'яса забійних тварин використовували аспіраційний метод (метод Андерсена) за допомогою пробовідбірника повітря TRIO.BAS (Україна). Через прилад пропуска-

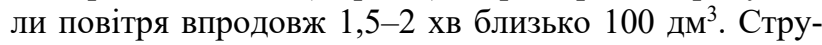
мінь повітря через отвори приладу зі швидкістю

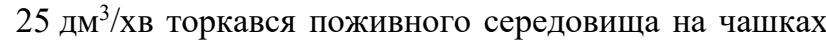
Петрі, використовуючи п'ять стерильних чашок Петрі 3 агаром, для малих холодильних камер - три чашки Петрі. Для дослідження загальної кількості плісеневих грибів, у тому числі й кладоспоріїв, використовували агар Сабуро. Чашки Петрі з відібраними пробами закривали кришками і поміщали в термостат для культивування: для визначення загального мікробного обсіменіння - за температури $30 \pm 1^{\circ} \mathrm{C}$ упродовж $72 \pm 3$ годин; для визначення обсіменіння пліснявою за температури (24-25) $\pm 1{ }^{\circ} \mathrm{C}$ упродовж 5 діб. Перший підрахунок плісняви проводили через 3 доби i для остаточного визначення виду плісняви посіви в чашках проглядали на 5 добу. Підрахунок кількості колоній плісеневих грибів, в тому числі кладоспоріїв (Cladosporium herbarum) в $1 \mathrm{~m}^{3}$ повітря, проводили за загальноприйнятим методом.

Відбір проб з об'єктів потужностей з виробництва та обігу (столів/прилавків, стін, підлоги, ножів, рук працівників) здійснювали стерильними ватномарлевими тампонами, змоченими стерильним нейтралізуючим розчином. Ділянки $10 \times 10 \mathrm{~cm}^{2}$ ретельно протирали тампоном та вміщували їх до пробірок. За наявності на об'єкті щільних забруднень їх знімали за допомогою стерильного скальпеля та переносили в цю ж пробірку. Для визначення бактеріальної забрудненості об'єктів використовували живильне середовище Сабуро за інкубування посівів у термостаті за температури $22 \ldots 24{ }^{\circ} \mathrm{C}$ упродовж $5 \ldots 10$ діб. Після цього підраховували колонії плісеневих грибів у розрахунку на 1 см$^{2}$ дослідної площі за загальноприйнятим методом відповідно до ДСТУ ISO 7954:2006 "Мікробіологія харчових продуктів i кормів для тварин. Загальні настанови 3 підрахунку дріжджів і мікроскопічних грибів. Техніка підрахування колоній, культивованих за температури $25^{\circ} \mathrm{C}$ ".

Визначали також на об'єктах потужностей з виробництва та обігу санітарно-показові мікроорганізми (вміст МАФАнМ, колі-титр, бактерій роду Echerichia,
Staphylococcus aureus) та патогенних (бактерій роду Salmonella, Listeria monocytogenes) за загальноприйнятими методиками згідно 3 національними стандартами (ДСТУ ISO 4833:2006 “Мікробіологія харчових продуктів і кормів для тварин. Горизонтальний метод підрахунку мікроорганізмів. Техніка підрахування колоній за температури $+30{ }^{\circ} \mathrm{C} "$; ДСТУ ISO 21528 1:2014 "Мікробіологія харчових продуктів і кормів для тварин. Горизонтальний метод виявлення і підрахування ентеробактерій (Enterobacteriaceae). Частина 1. Виявлення та підрахування за методикою НІЧ 3 попереднім збагаченням"; ДСТУ ISO 6888-1:2003 "Мікробіологія харчових продуктів та кормів для тварин. Горизонтальний метод підрахування коагулазопозитивних стафілококів (Staphylococcus aureus та інших видів). Частина 1. Метод 3 використанням агарового середовища Беард Паркера"; ДСТУ ISO 6579:2006 “Мікробіологія харчових продуктів і кормів для тварин. Методика виявлення Salmonella spp.”; ДСТУ ISO 11290-1:2003 “Мікробіологія харчових продуктів та кормів для тварин. Горизонтальний метод виявлення та підрахування Listeria monocytogenes. Частина 1. Метод виявлення") та Методичних вказівок щодо санітарно-мікробіологічного контролю об'єктів виробництва та реалізації, які підлягають ветеринарному нагляду (Garkavenko et al., 2014).

Відбір змивів з поверхні м'яса забійних тварин, що зберігалось у холодильних камерах потужностей 3 виробництва та обігу, проводили стерильним тампоном згідно 3 вимогами національного стандарту ДСТУ ISO 17604:2014 “Мікробіологія харчових продуктів і кормів для тварин. Відбирання проб із туш тварин для мікробіологічного аналізу”.

Визначення вмісту МАФАнМ на поверхні м'яса забійних тварин проводили шляхом змивів 3 поверхні м'язової тканини і приготування розведень 1:10, 1:100, 1:1000, 1:10000, 1:100000, 1:1000000 відповідно вимог чинного ДСТУ ISO 6887-1:1999 “Мікробіологія харчових продуктів і кормів для тварин. Готування досліджуваних проб, вихідної суспензії та десятикратних розведень для мікробіологічного дослідженя. Частина 1. Загальні правила готування вихідної суспензії та десятикратних суспензій”. У подальшому по $1 \mathrm{~cm}^{3}$ із кожного розведення переносили у стерильні чашки Петрі та заливали розплавленим і охолодженим до $55^{\circ} \mathrm{C}$ м'ясо-пептонним агаром 3 подальшою інкубацією посівів у термостаті за температури $37^{\circ} \mathrm{C}$ упродовж 48 год.

Вірогідність проведених досліджень підтверджується використанням сертифікованого обладнання, сучасних методів випробувань при застосуванні статистичної обробки даних результатів.

\section{Результати та їх обговорення}

3 метою виявлення негативного впливу на безпечність м'яса забійних тварин за його зберігання та обігу нами були проведені дослідження для вивчення бактеріального забруднення холодильних камер за вмістом МАФАнМ плісеневими грибами, у т. ч. кладоспоріями. Нашими дослідженнями були встановле- 
ні показники санітарно-мікробіологічного контролю повітря холодильних камер на потужностях $з$ виробництва та обігу м'яса забійних тварин за різних температур (від $4 \pm 2{ }^{\circ} \mathrm{C}$ до $-12{ }^{\circ} \mathrm{C}$ ), відносної вологості повітря (80, 88, 90 та 95 \%), що була в межах норми та різного терміну зберігання м'яса забійних тварин (2 доби; 16, 20 діб, 3, 6 та 8 місяців).

У таблиці 1 наведені результати санітарномікробіологічного контролю забруднення повітря холодильних камер на потужностях 3 виробництва та обігу м’яса забійних тварин.

\section{Таблиця 1}

Показники санітарно-мікробіологічного контролю повітря в холодильних камерах на потужностях 3 виробництва та обігу м’яса забійних тварин, КУО/м³ $, \mathrm{M} \pm \mathrm{m}, \mathrm{n}=58$

\begin{tabular}{|c|c|c|c|}
\hline \multirow{2}{*}{$\begin{array}{c}\text { Кількість } \\
\text { досліджуваних } \\
\text { проб повітря }\end{array}$} & \multirow{2}{*}{$\begin{array}{c}\text { Кількість чашок } \\
\text { Петрі із середови- } \\
\text { щем Сабуро }\end{array}$} & \multicolumn{2}{|c|}{$\begin{array}{c}\text { Санітарно-мікробіологічні показники під час завантаження і зберігання м’яса } \\
\text { забійних тварин }\end{array}$} \\
\hline & & $\begin{array}{c}\text { середня кількість } \\
\text { плісеневих грибів } \\
\text { КУО/М }{ }^{3}\end{array}$ & $\begin{array}{l}\text { у тому числі } \\
\text { Cladosporium } \\
\text { herbarum }\end{array}$ \\
\hline \multicolumn{4}{|c|}{ Холодильна камера на потужності з виробництва м’яса забійних тварин за температури $-12{ }^{\circ} \mathrm{C}$ та відносної вологості 95 o } \\
\hline 12 & 60 & $(0,39 \pm 0,04) \times 10^{2}$ & - \\
\hline \multicolumn{4}{|c|}{$\begin{array}{c}\text { Холодильна камера на потужності з виробництва м’яса забійних тварин за температури }-2 \ldots-3{ }^{\circ} \mathrm{C} \\
\text { та відносної вологості } 90 \%\end{array}$} \\
\hline 10 & 50 & $(0,52 \pm 0,05) \times 10^{2 *} \quad 8 \pm 2$ & 1 \\
\hline \multicolumn{4}{|c|}{$\begin{array}{c}\text { Холодильна камера на оптовій базі при зберіганні м’яса забійних тварин за температури }-12 \text { º } \\
\text { та відносної вологості } 95 \%\end{array}$} \\
\hline 12 & 60 & $(0,41 \pm 0,04) \times 10^{2} \quad 7 \pm 2$ & - \\
\hline \multicolumn{4}{|c|}{$\begin{array}{c}\text { Холодильна камера на оптовій базі при зберіганні м’яса забійних тварин за температури }-2 \ldots-3{ }^{\circ} \mathrm{C} \\
\text { та відносної вологості } 90 \%\end{array}$} \\
\hline 10 & 50 & $(1,19 \pm 0,09) \times 10^{2 * * *}$ & 1 \\
\hline \multicolumn{4}{|c|}{$\begin{array}{c}\text { Холодильна камера у супермаркеті при реалізації м’яса забійних тварин за температури }-6 \ldots-8{ }^{\circ} \mathrm{C} \\
\text { та відносної вологості } 85 \%\end{array}$} \\
\hline 8 & 24 & $32,00 \pm 0,74 * * *$ & $2 \pm 1$ \\
\hline \multicolumn{4}{|c|}{$\begin{array}{c}\text { Холодильна відкрита вітрина у супермаркеті при реалізації м’яса забійних тварин за температури } 4 \pm 2{ }^{\circ} \mathrm{C} \\
\text { та відносної вологості } 82 \%\end{array}$} \\
\hline 8 & 24 & $(1,72 \pm 0,08) \times 10^{2 * * *} \quad 65,00 \pm 1,04$ & $2 \pm 1$ \\
\hline \multicolumn{4}{|c|}{$\begin{array}{c}\text { Приміщення з реалізації м’яса забійних тварин на агропродовольчих ринках за температури } 0 \ldots 6^{\circ} \mathrm{C} \\
\text { та відносної вологості } 88 \%\end{array}$} \\
\hline 7 & 21 & $(2,19 \pm 0,11) \times 10^{2}$ & $5 \pm 1$ \\
\hline \multicolumn{4}{|c|}{$\begin{array}{c}\text { Камера охолодження при реалізації м’яса забійних тварин на агропродовольчих ринках за температури } 0 \ldots-1{ }^{\circ} \mathrm{C} \\
\text { та відносної вологості } 85 \%\end{array}$} \\
\hline 7 & 21 & $(1,89 \pm 0,09) \times 10^{2 *}$ & $2 \pm 1^{*}$ \\
\hline
\end{tabular}
Примітка: *-P $\leq 0,05 ; * * *-\mathrm{P} \leq 0,001$

Найбільший вміст МАФАнМ у повітрі був у холодильній камері супермаркету за температури $4 \pm 2{ }^{\circ} \mathrm{C}$ - $(1,72 \pm 0,08) \times 10^{2} \mathrm{KУO} / \mathrm{M}^{3}$ на 2 добу та у камері охолодження при реалізації м'яса забійних тварин на агропродовольчому ринку за температури $0 \ldots-1{ }^{\circ} \mathrm{C}$ на 16 добу - $(1,89 \pm 0,09) \times 10^{2} \mathrm{KУО} / \mathrm{m}^{3}$. А перевищення нормативів вмісту МАФАнМ в повітрі (понад $200 \mathrm{KУO} / \mathrm{M}^{3}$ ) було встановлено в приміщенні реалізації м'яса забійних тварин на агропродовольчому ринку $-2,19 \times 10^{2} \mathrm{KУО} / \mathrm{M}^{3}$ за температури $0 \ldots 6^{\circ} \mathrm{C}$. Високої вірогідності були встановлені показники вмісту МАФАнМ у повітрі холодильної камери (полиці) за температури $4 \pm 2{ }^{\circ} \mathrm{C}$ на 2 добу в супермаркеті у 2,82 разу більше $(\mathrm{P} \leq 0,001)$ порівняно $з$ показниками у холодильній камері за темпратури $-6 \ldots-8{ }^{\circ} \mathrm{C}$ на 20 добу; у повітрі холодильної камери оптової бази при зберіганні м'яса забійних тварин за температури $-2 \ldots-3{ }^{\circ} \mathrm{C}$ на 20 добу в 2,90 разу $(\mathrm{P} \leq 0,001)$ більше порівняно 3 показниками у холодильних камерах за температури від $-12{ }^{\circ} \mathrm{C}$.

Аналізуючи таблицю 1, можна зробити висновок, що завдяки використанню температури $-12{ }^{\circ} \mathrm{C}$ у холодильній камері потужності з виробництва м'яса забій- них тварин та оптовій базі досягнуто поліпшення санітарного стану холодильних камер за умови збереження показників якості м'яса забійних тварин. А за використання температури $0 \ldots-1{ }^{\circ} \mathrm{C},-6 \ldots-8{ }^{\circ} \mathrm{C}$ холодильних камер у супермаркеті, а також за температури $0 \ldots-1{ }^{\circ} \mathrm{C}$ холодильної камери агропродовольчого ринку спостерігався задовільний санітарний стан. За використання температури $0 \ldots 6^{\circ} \mathrm{C}$ у холодильній камері агропродовольчого ринку - незадовільний санітарний стан, оскільки вміст плісеневих грибів перевищував нормативи і складав $-103,00 \pm 2,24 \mathrm{KУO} / \mathrm{M}^{3}$, в тому числі $5 \pm 1$ Cladosporium herbarum.

Інспекторам ветеринарної медицини необхідно здійснювати контроль технологічного процесу охолодження м'яса забійних тварин на наявність у повітрі мікроскопічних плісеневих грибів, особливо кладоспоріїв. Інспекційні перевірки необхідно здійснювати на підставі оцінки ризиків, вони мають запобігти перехресному забрудненню в забійному цеху і холодильних камерах, а також якість інспекції м'яса необхідно поліпшувати шляхом запровадження суворих гігієнічних вимог на рівні ферми (Buchanan et al., 1998). Кладоспорії здатні проявляти свої токсикогенні 
властивості якраз за низьких температурних режимів охолодженого м'яса, що може призвести до отруєння споживачів під час його споживання, реалізації або подальшого зберігання, тому що таке м'ясо контаміноване кладоспоріями через повітря за тимчасового зберігання у камері для охолодження (Dwinger et al., 2008).
На рис. 1 - санітарно-мікробіологічні показники змивів з об'єктів холодильних камер та рук працівників $(\mathrm{n}=24)$ потужностей з виробництва та зберігання м'яса забійних тварин за різної температури та відносної вологості.

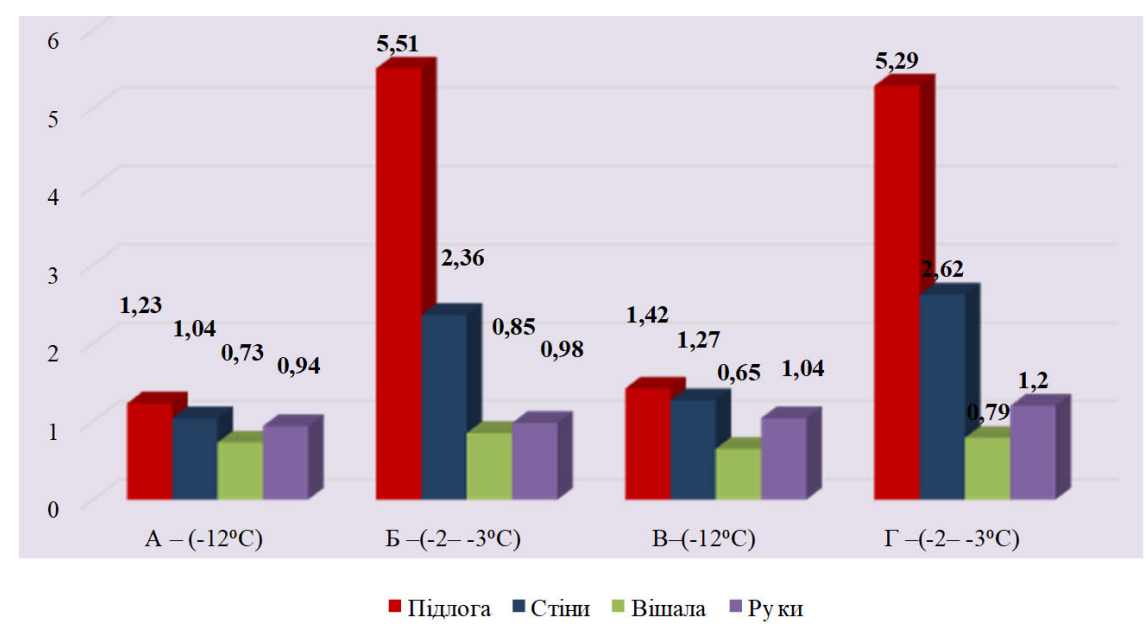

Рис. 1. Санітарно-мікробіологічні показники змивів з об’єктів холодильних камер та рук працівників потужностей з виробництва та зберігання м'яса забійних тварин за вмістом МАФАнМ $\times 10^{1}$

(А - холодильна камера потужності з виробництва м'яса забійних тварин за температури $-12{ }^{\circ} \mathrm{C}$; Б - холодильна камера потужності з виробництва м'яса забійних тварин за температури $-2 \ldots-3{ }^{\circ} \mathrm{C}$; В - холодильна камера оптової бази за температури $-12{ }^{\circ} \mathrm{C} ; \Gamma-$ холодильна камера оптової бази за температури $-2 \ldots-3{ }^{\circ} \mathrm{C}$ )

Необхідно зазначити, що за температури $-2 \ldots-3{ }^{\circ} \mathrm{C}$ у холодильній камері потужності з виробництва м'яса забійних тварин найвищий вміст МАФАнМ високої ступені вірогідності виявляли у змивах із підлоги - у 4,48 разу більше $(\mathrm{P} \leq 0,001)$, стін - у 2,27 разу $(\mathrm{P} \leq 0,001)$ та вішал - у 1,16 разу більше $(\mathrm{P} \leq 0,001)$ порівняно $з$ показниками у холодильній камері за температури $-12{ }^{\circ} \mathrm{C}$. Не встановлено було вірогідної різниці вмісту МАФАнМ у змивах із рук працівників. Також за температури $-2 \ldots-3{ }^{\circ} \mathrm{C}$ у холодильній камері оптової бази при зберіганні м'яса забійних тварин найвищий вміст МАФАнМ високого ступеня вірогідності виявляли у змивах із підлоги - у 3,73 разу $(\mathrm{P} \leq 0,001)$ більше, стін - у 2,06 разу $(\mathrm{P} \leq 0,001)$ та вішал - у 1,22 разу більше $(\mathrm{P} \leq 0,001)$ порівняно 3 показниками із змивів об'єктів у холодильній камері за температури $-12{ }^{\circ} \mathrm{C}$. Не встановлено було вірогідної різниці вмісту МАФАнМ у змивах із рук працівників, але спостерігалась тенденція до збільшення у 1,04 та 1,15 разу порівняно з показниками вмісту МАФАнМ зі змивів рук працівників холодильної камери за температури $-12{ }^{\circ} \mathrm{C}$.

За температури $-12{ }^{\circ} \mathrm{C}$ у холодильній камері 3 об'єктів і рук працівників на потужностях з виробництва та зберігання м'яса забійних величина колі-титру в змивній рідині становила більше ніж 1 (добрий санітарний стан), а за температури $-2 \ldots-3{ }^{\circ} \mathrm{C}$ дорівнювала 1 (задовільний санітарний стан).

На рис. 2 - санітарно-мікробіологічні показники змивів з об'єктів холодильних камер, ножів та рук працівників $(\mathrm{n}=24)$ потужностей з реалізації м'яса забійних тварин за різної температури та відносної вологості.
За використання температури $4 \pm 2{ }^{\circ} \mathrm{C}$ у холодильній камері супермаркету найбільший вміст МАФАнМ високого ступеня вірогідності встановили зі змивів об'єктів, а саме: зі змивів із підлоги $(1,83 \pm 0,06) \times 10^{2} \mathrm{KУО} / \mathrm{cm}^{2}$, що у 3,07 разу більше $(\mathrm{P} \leq$ $0,001)$, стін - $(1,14 \pm 0,07) \times 10^{2} \mathrm{KУO} / \mathrm{cm}^{2}$ у 2,73 разу $(\mathrm{P} \leq 0,001)$, столів - $(1,49 \pm 0,05) \times 10^{2} \mathrm{KУO} / \mathrm{cm}^{2}$, що у 4,78 разу $(\mathrm{P} \leq 0,001)$, ножів $-(4,10 \pm 0,12) \times 10^{1} \mathrm{KУO} / \mathrm{cm}^{2}$, що у 1,42 разу $(\mathrm{P} \leq 0,001)$ та із рук працівників $(8,23 \pm 0,11) \times 10^{1} \mathrm{KУО} / \mathrm{cm}^{2}$, що у 1,23 разу більше порівняно з показниками вмісту МАФАнМ із об'єктів холодильної камери за температури $-6 . .-8^{\circ} \mathrm{C}$.

За температури $0 \ldots 6^{\circ} \mathrm{C}$ у холодильній камері агропродовольчого ринку також нашими дослідженнями була встановлена тенденція до підвищення вмісту МАФАнМ із змивів об'єктів, проте різниця була не вірогідною, а саме: із змивів 3 підлоги $(2,24 \pm 0,14) \times 10^{2} \mathrm{KУO} / \mathrm{cm}^{2}$, що у 1,13 рази більше $(\mathrm{P} \leq 0,001)$, стін $-(1,08 \pm 0,07) \times 10^{2} \mathrm{KУO} / \mathrm{cm}^{2}$ у 1,10 разу $(\mathrm{P} \leq 0,001)$, столів - $(1,73 \pm 0,10) \times 10^{2} \mathrm{KУO} / \mathrm{cm}^{2}$, що у 1,09 разу $(\mathrm{P} \leq 0,001)$, ножів $-(1,37 \pm 0,10) \times 10^{2} \mathrm{KУO} / \mathrm{cm}^{2}$, що у 1,06 рази $(\mathrm{P} \leq 0,001)$ та із рук працівників $(1,63 \pm 0,13) \times 10^{2} \mathrm{KУО} / \mathrm{cm}^{2}$, що в 1,16 разу більше порівняно з показниками вмісту МАФАнМ із об'єктів холодильної камери за температури $0 \ldots-1{ }^{\circ} \mathrm{C}$.

За температури $-6 \ldots-8{ }^{\circ} \mathrm{C}$ у холодильній камері 3 об'єктів ножів і рук працівників у супермаркетах за реалізації м'яса забійних тварин величина колі-титру в змивній рідині становила 1 (задовільний санітарний стан), а за температури $4 \pm 2{ }^{\circ} \mathrm{C}-$ менше ніж 1 (незадовільний санітарний стан). 


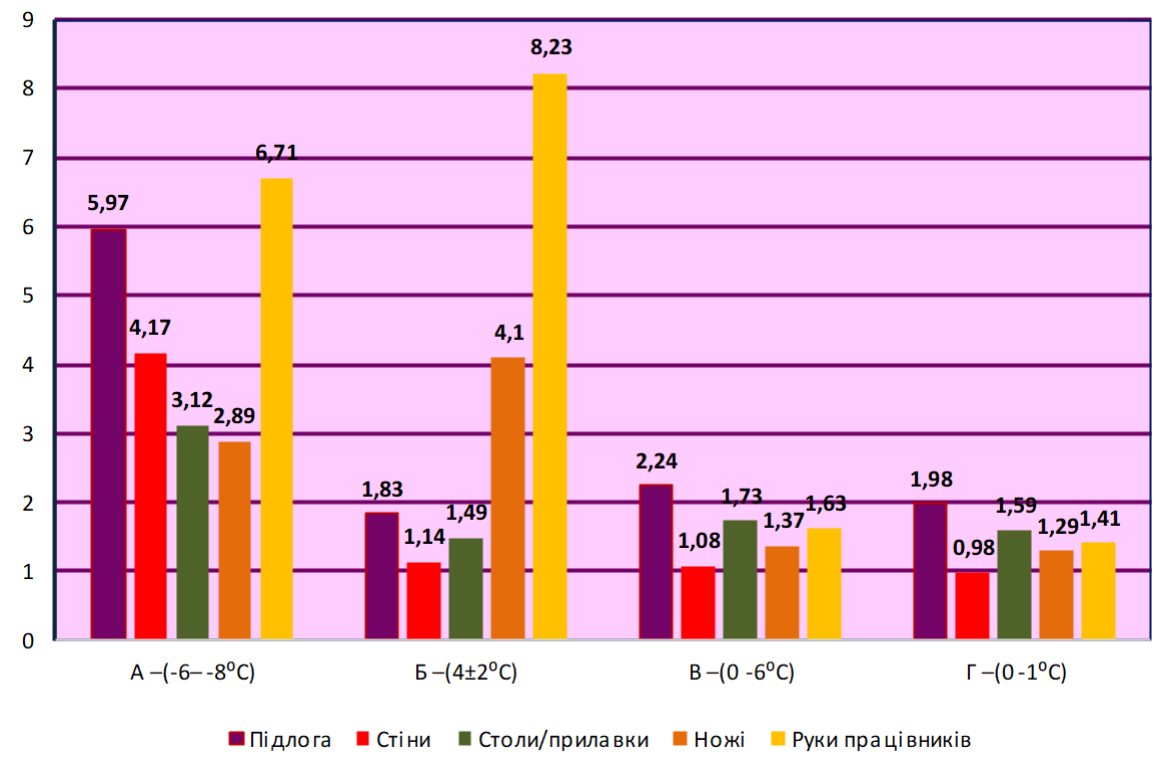

Рис. 2. Санітарно-мікробіологічні показники змивів з об’єктів холодильних камер, ножів та рук працівників потужностей з реалізації м'яса забійних тварин за вмістом МАФАнМ

(А - холодильна камера супермаркету за температури $-6 \ldots-8{ }^{\circ} \mathrm{C}$ (вміст МАФАнМ $\times 10^{1}$ ); Б - холодильна камера (полиця) супермаркету за температури $4 \pm 2{ }^{\circ} \mathrm{C}$ (вміст МАФАнМ $\times 10^{2}$ ) - для підлоги, стін, прилавків; вміст МАФАнМ $\times 10^{1}-$ для ножів, рук працівників); В - холодильна камера (приміщення) на агропродовольчому ринку за температури $0 \ldots 6^{\circ} \mathrm{C}$ (вміст МАФАнМ $\left.\times 10^{2}\right) ; \Gamma$ - камера охолодження на агропродовольчому ринку за температури $0 \ldots-1{ }^{\circ} \mathrm{C}\left(\right.$ вміст МАФАнМ $\left.\times 10^{2}\right)$

\section{Таблиця 2}

Частота виділених тест-культур зі змивів об’єктів на потужностях з виробництва та обігу м’яса забійних тварин, $\mathrm{n}=24$

\begin{tabular}{|c|c|c|c|c|c|}
\hline \multirow{2}{*}{$\begin{array}{l}\text { Тест-культури } \\
\text { бактерій роду }\end{array}$} & \multicolumn{5}{|c|}{ Частота виділених тест-культур, кількість проб/ \% } \\
\hline & підлога & стіни & вішала/столи/прилавки & ножі & руки працівників \\
\hline \multicolumn{6}{|c|}{ Холодильна камера на потужності з виробництва м’яса забійних тварин за температури - 12 ㄷ та відносної вологості 95 \% } \\
\hline Echerichia & $3 / 12,5$ & $1 / 4,2$ & $1 / 4,2$ & - & $2 / 8,3$ \\
\hline Salmonella & - & - & - & - & - \\
\hline Staphylococcus aureus & - & - & - & - & - \\
\hline \multicolumn{6}{|c|}{ Холодильна камера на потужності з виробництва м’яса забійних тварин за температури $-2 \ldots-.3^{\circ} \mathrm{C}$ та відносної вологості 90 \% } \\
\hline Echerichia & $4 / 16,7$ & $2 / 8,3$ & $1 / 4,2$ & - & $2 / 8,3$ \\
\hline Salmonella & - & - & - & - & - \\
\hline Staphylococcus aureus & $2 / 8,3$ & $3 / 12,5$ & - & - & - \\
\hline \multicolumn{6}{|c|}{ Холодильна камера на оптовій базі при зберіганні м’яса забійних тварин за температури - $12{ }^{\circ} \mathrm{C}$ та відносної вологості 95 \% } \\
\hline Echerichia & $2 / 8,3$ & $3 / 12,5$ & $2 / 8,3$ & - & $3 / 12,5$ \\
\hline Salmonella & - & - & - & - & - \\
\hline Staphylococcus aureus & $1 / 4,2$ & $1 / 4,2$ & - & - & - \\
\hline \multicolumn{6}{|c|}{ Холодильна камера на оптовій базі при зберіганні м’яса забійних тварин за температури $-2 \ldots-3{ }^{\circ} \mathrm{C}$ та відносної вологості 90 \% } \\
\hline Echerichia & $5 / 20,8$ & $2 / 8,3$ & - & - & $4 / 16,7$ \\
\hline Salmonella & - & - & - & - & - \\
\hline Staphylococcus aureus & $2 / 8,3$ & $1 / 4,2$ & - & - & - \\
\hline \multicolumn{6}{|c|}{ Холодильна камера у супермаркеті при реалізації м'яса забійних тварин за температури $-6 \ldots-8{ }^{\circ} \mathrm{C}$ та відносної вологості 85 \% } \\
\hline Echerichia & $4 / 16,7$ & $2 / 8,3$ & $3 / 12,5$ & $2 / 8,3$ & $3 / 12,5$ \\
\hline Salmonella & $3 / 12,5$ & - & - & - & $2 / 8,3$ \\
\hline Staphylococcus aureus & $2 / 8,3$ & - & - & - & $1 / 4,2$ \\
\hline \multicolumn{6}{|c|}{$\begin{array}{c}\text { Холодильна камера (полиця) у супермаркеті при реалізації м’яса забійних тварин за температури } 4 \pm 2{ }^{\circ} \mathrm{C} \\
\text { та відносної вологості } 82 \%\end{array}$} \\
\hline Echerichia & $12 / 50,0$ & $5 / 20,8$ & $9 / 37,5$ & $3 / 12,5$ & $6 / 25,0$ \\
\hline Salmonella & $3 / 12,5$ & $2 / 8,3$ & $4 / 16,7$ & - & $3 / 12,5$ \\
\hline Staphylococcus aureus & $5 / 20,8$ & $1 / 4,2$ & - & - & $2 / 8,3$ \\
\hline \multicolumn{6}{|c|}{$\begin{array}{c}\text { Приміщення з реалізації м’яса забійних тварин на агропродовольчому ринку за температури } 0 \ldots 6{ }^{\circ} \mathrm{C} \\
\text { та відносної вологості } 88 \%\end{array}$} \\
\hline Echerichia & $8 / 33,3$ & $5 / 20,8$ & $10 / 41,7$ & $4 / 16,7$ & $3 / 12,5$ \\
\hline Salmonella & $3 / 12,5$ & $2 / 8,3$ & $2 / 8,3$ & $2 / 8,3$ & $4 / 16,7$ \\
\hline Staphylococcus aureus & $4 / 16,7$ & $3 / 12,5$ & $8 / 33,3$ & $3 / 12,5$ & $3 / 12,5$ \\
\hline \multicolumn{6}{|c|}{$\begin{array}{c}\text { Камера охолодження при реалізації м’яса забійних тварин на агропродовольчому ринку за температури } 0 \ldots-1{ }^{\circ} \mathrm{C} \\
\text { та відносної вологості } 85 \%\end{array}$} \\
\hline Echerichia & $5 / 20,8$ & $6 / 25,0$ & $11 / 45,8$ & $2 / 8,3$ & $12 / 50,0$ \\
\hline Salmonella & $2 / 8,3$ & $2 / 8,3$ & $3 / 12,5$ & $1 / 4,2$ & $3 / 12,5$ \\
\hline Staphylococcus aureus & $3 / 12,5$ & $2 / 8,3$ & $7 / 29,7$ & $1 / 4,2$ & $5 / 20,8$ \\
\hline
\end{tabular}


Також за температури $0 \ldots 6^{\circ} \mathrm{C}$ та $0 \ldots-1{ }^{\circ} \mathrm{C}$ у холодильних камерах із об'єктів ножів і рук працівників на агропродовольчому ринку величина колі-титру в змивній рідині становила менше ніж 1 (задовільний санітарний стан).

Було встановлено частоту виділених тест-культур зі змивів об'єктів потужностей з виробництва та обігу м'яса забійних тварин, ножів та рук працівників за кількістю проб і перерахунку у відсоток від загальної кількості досліджуваних проб.

Отримані результати (табл. 2) свідчать, що за температури $0 \ldots 6^{\circ} \mathrm{C}$ та $0 \ldots-1{ }^{\circ} \mathrm{C}$ у холодильних камерах на об'єктах, ножах та руках працівників на агропродовольчому ринку було встановлено високу частоту виділених тест-культур бактерій роду Echerichia, Salmonella та Staphylococcus aureus. Так, за температури $0 \ldots 6{ }^{\circ} \mathrm{C}$ у холодильній камері зі змивів об'єктів, ножів і рук працівників були виділені бактерії групи Echerichia до $41,7 \%$, бактерій роду Salmonella до 16,7 \%, бактерій роду Staphylococcus aureus до 33,3 \%, а за температури $0 \ldots-1{ }^{\circ} \mathrm{C}$ у холодильній камері зі змивів об'єктів, а також ножів і рук працівників бактерії групи Echerichia до 50,0\%, бактерій роду Salmonella до $12,5 \%$, бактерій роду Staphylococcus aureus до 29,7 \%.

За температури від $-6 \ldots-8{ }^{\circ} \mathrm{C}$ у холодильній камері супермаркету зі змивів об'єктів, ножів і рук працівників були виділені бактерії роду Echerichia до 16,7 \%, бактерії роду Salmonella до $12,5 \%$, бактерії роду Staphylococcus aureus до 8,3\%, а за температури $4 \pm 2{ }^{\circ} \mathrm{C}$ у холодильній камері зі змивів об'єктів, а також ножів і рук працівників - бактерії роду Echerichia до 50,0\%, бактерій роду Salmonella до 16,7 \%, бактерії роду Staphylococcus aureus до 20,8 \%.

За температури від $-12{ }^{\circ} \mathrm{C}$ у холодильній камері на оптовій базі зі змивів об'єктів та рук працівників були виділені бактерії роду Echerichia до 12,5 \%, бактерії роду Staphylococcus aureus до 4,2 \%, а за температури $-2 \ldots-3{ }^{\circ} \mathrm{C}$ у холодильній камері зі змивів об'єктів та рук працівників - бактерії роду Echerichia до 20,8 \%, бактерії роду Staphylococcus aureus до 8,3 \% (із підлоги і стін). Бактерій роду Salmonella не було виявлено.

За температури від $-12{ }^{\circ} \mathrm{C}$ у холодильній камері на потужності 3 виробництва м'яса забійних тварин із змивів об'єктів та рук працівників були виділені бактерії роду Echerichia до 12,5 \%, бактерій роду Salmonella та Staphylococcus aureus не було виявлено; за температури $-2 \ldots-3{ }^{\circ} \mathrm{C}$ у холодильній камері зі змивів об'єктів та рук працівників - бактерії роду Echerichia до 16,7 \%, бактерії роду Staphylococcus aureus до 12,5 \% (із підлоги і стін). Бактерій роду Salmonella не було виявлено.

Бактерії роду Listeria monocytogenes зі змивів об'єктів у холодильних камер потужностей з виробництва та обігу м'яса забійних тварин, ножах і руках працівників не було виявлено.

За підтвердження даними показниками виділених тест-культур неналежного санітарно-гігієнічного стану холодильних камер та інших об'єктів агропродовольчого ринку, супермаркету необхідно здійснювати ретельне прибирання, а також вимушений і по- вторний контроль якості дезінфекції інспекторами ветеринарної медицини. Тому що це може призвести до обсіменіння м'яса забійними бактеріями родів Echerichia, Salmonella та Staphylococcus aureus, яке зберігається в холодильних камерах. Автор (Ichakova, 2011) стверджує, що значна частота виділених тесткультур на м'ясопереробній потужності припадала на ешеріхії (30\% на тару, $25 \%$ на підлогу, 16,75 \% на інструменти, $15 \%$ на нижню частину стіни), стафілококи (70 \% на тарі, 66,7 \% на підлозі, 50 \% на інструментах).

Було встановлено бактеріальне забруднення м'яса забійних тварин в його кінцевий нормативний термін зберігання на потужностях з виробництва та обігу під час зберігання та реалізації в холодильних камерах за різних температур та відносної вологості повітря. Результати наведені у таблиці 3.

За температури $-2 \ldots-3{ }^{\circ} \mathrm{C}$ у холодильній камері за відносної вологості 90 \% на потужності з виробництва м'яса на 20 добу зберігання вміст МАФАнМ на поверхні м'яса забійних тварин був вірогідно вищим: у свинині - у 1,29 разу більше $(\mathrm{P} \leq 0,001)$, у баранині у 1,36 разу $(\mathrm{P} \leq 0,001)$, у козлятині - у 1,46 разу більше $(\mathrm{P} \leq 0,001)$, а в яловичині спостерігалася низька вірогідність - у 1,21 разу більше $(\mathrm{P} \leq 0,05)$ порівняно 3 показниками у м'ясі забійних тварин, що зберігалося в холодильній камері за температури $-12^{\circ} \mathrm{C}$ та відносної вологості 95 \% (яловичини - на 8 міс., свинини на 3 міс., баранини і козлятини - на 6 міс.).

За температури $-2 \ldots-3{ }^{\circ} \mathrm{C}$ у холодильній камері за відносної вологості $90 \%$ на оптовій базі на 20 добу зберігання м'яса забійних тварин вміст МАФАнМ також був дещо вищим порівняно з показниками у м'ясі при зберіганні в холодильній камері за температури $-12{ }^{\circ} \mathrm{C}$ та відносної вологості $95 \%$ : у яловичині на 8 місяць - у 1,05 разу більше, у свинині на 3 місяць - у 1,26 разу $(\mathrm{P} \leq 0,05)$, у баранині на 6 місяць - у 1,32 разу $(\mathrm{P} \leq 0,01)$, у козлятині на 6 місяць - у 1,29 разу більше.

За температури $4 \pm 2{ }^{\circ} \mathrm{C}$ у холодильній камері за відносної вологості 82 \% у супермаркеті на 2 добу реалізації вміст МАФАнМ на поверхні м'яса забійних тварин був значно підвищеним: у яловичині - у $1,39$ разу більше, у свинині - у 1,78 разу ( $\mathrm{P} \leq 0,01)$, $\mathrm{y}$ баранині - у 1,68 разу $(\mathrm{P} \leq 0,05)$ та у козлятині $-\mathrm{y}$ 1,20 разу більше порівняно з показниками у м'ясі при реалізації в супермаркеті 3 холодильної камери за температури $-6 \ldots-8{ }^{\circ} \mathrm{C}$ та відносної вологості $85 \%$ на 20 добу.

За температури $0 \ldots-6{ }^{\circ} \mathrm{C}$ у холодильній камері / приміщенні за відносної вологості 88 \% на агропродовольчому ринку на 2 добу реалізації м'яса забійних тварин вміст МАФАнМ був вищим і різниця була вірогідною: у яловичині - у 1,85 разу більше ( $\mathrm{P} \leq 0,001)$, у свинині - у 1,98 разу $(\mathrm{P} \leq 0,001)$, у баранині - у 1,82 разу $(\mathrm{P} \leq 0,01)$ та у козлятині $-\mathrm{y}$ 1,82 разу більше $(\mathrm{P} \leq 0,001)$ порівняно з показниками у м'ясі за реалізації на агропродовольчому ринку із холодильної камери за температури $0 \ldots-1{ }^{\circ} \mathrm{C}$ та відносної вологості 85 \% на 16 добу. 
Таблиця 3

Вміст МАФАнМ на поверхні м'яса забійних тварин, що зберігалися у холодильних камерах потужностей різних типів, КУО/ $\mathrm{cm}^{2}, \mathrm{M} \pm \mathrm{m}, \mathrm{n}=9$

\begin{tabular}{|c|c|c|}
\hline Вид м'яса забійних тварин & \multicolumn{2}{|c|}{$\begin{array}{c}\text { Вміст МАФАнМ, КУО/г за зберігання м’яса забійних тварин на різних типах } \\
\text { потужностях }\end{array}$} \\
\hline \multicolumn{3}{|c|}{ Холодильні камери на потужностях з виробництва м’яса забійних тварин } \\
\hline $\begin{array}{l}\text { Температура і відносна } \\
\text { вологість }\end{array}$ & $\begin{array}{l}\text { за температури }-12{ }^{\circ} \mathrm{C} \text { та відносної } \\
\text { вологості } 95 \%\end{array}$ & $\begin{array}{l}\text { температури }-2 \ldots-3{ }^{\circ} \mathrm{C} \text { та відносної вологості } \\
90 \% \text { на } 20 \text { добу }\end{array}$ \\
\hline Яловичина ${ }^{1}$ & $(2,56 \pm 0,18) \times 10^{2}$ & $(3,11 \pm 0,20) \times 10^{2 *}$ \\
\hline Свинина $^{2}$ & $(2,69 \pm 0,14) \times 10^{2}$ & $(3,48 \pm 0,12)>$ \\
\hline Баранина ${ }^{3}$ & $(1,85 \pm 0,17) \times 10^{2}$ & $(2,51 \pm 0,19) \times 10^{2 * *}$ \\
\hline Козлятина ${ }^{3}$ & $(1,77 \pm 0,16) \times 10^{2}$ & $(2,63 \pm 0,17) \times 10^{2 * * *}$ \\
\hline \multicolumn{3}{|c|}{ Холодильні камери на оптових базах за зберігання м'яса забійних тварин } \\
\hline $\begin{array}{l}\text { Температура і відносна } \\
\text { вологість }\end{array}$ & $\begin{array}{l}\text { за температури }-12{ }^{\circ} \mathrm{C} \text { та відносної } \\
\text { вологості } 95 \%\end{array}$ & $\begin{array}{l}\text { температури }-2 \ldots-3{ }^{\circ} \mathrm{C} \text { та відносної вологості } \\
90 \%\end{array}$ \\
\hline Яловичина ${ }^{1}$ & $(2,73 \pm 0,23) \times 10^{2}$ & $(2,86 \pm 0,13) \times 10^{2}$ \\
\hline Свинина $^{2}$ & $(2,44 \pm 0,21) \times 10^{2}$ & $(3,07 \pm 0,17) \times 10^{2 *}$ \\
\hline Баранина ${ }^{3}$ & $(2,51 \pm 0,18) \times 10^{2}$ & $(3,31 \pm 0,19) \times 10^{2 * *}$ \\
\hline Козлятина ${ }^{3}$ & $(2,13 \pm 0,12) \times 10^{2}$ & $(2,75 \pm 0,16) \times 10^{2}$ \\
\hline \multicolumn{3}{|c|}{ Холодильні камери у супермаркетах за реалізації м'яса забійних тварин } \\
\hline $\begin{array}{l}\text { Температура і відносна } \\
\text { вологість }\end{array}$ & $\begin{array}{l}\text { за температури }-6 \ldots-8{ }^{\circ} \mathrm{C} \text { та відносної } \\
\text { вологості } 85 \% \text { на } 20 \text { добу }\end{array}$ & $\begin{array}{l}\text { за температури } 4 \pm 2{ }^{\circ} \mathrm{C} \text { та відносної волого- } \\
\text { сті } 82 \% \text { на } 2 \text { добу }\end{array}$ \\
\hline Ялог & ,14) $\times 10^{3}$ & $(1,15 \pm 0,22) \times 10^{3}$ \\
\hline Сви & $\times 10^{3}$ & $\times 10^{3 * *}$ \\
\hline Бар & $\times 10^{3}$ & $\times 10^{3 *}$ \\
\hline Козлятина & $(0,98 \pm 0,15) \times 10^{3}$ & $(1,18 \pm 0,12) \times 10^{3}$ \\
\hline \multicolumn{3}{|c|}{ Холодильні камери/приміщення на агропродовольчих ринках за реалізації м'яса забійних тварин } \\
\hline Температура і відносна & $\begin{array}{l}\text { за температури } 0 \ldots-1{ }^{\circ} \mathrm{C} \text { та відносної } \\
\text { вологості } 85 \% \text { на } 16 \text { добу }\end{array}$ & за температури $0 \ldots 6^{\circ} \mathrm{C}$ та відносної волого- \\
\hline Яловичина & $(1,22 \pm 0,23) \times 10^{3}$ & $(2,26 \pm 0,21) \times 10^{3 * * *}$ \\
\hline Свинина & $(1,42 \pm 0,18) \times 10^{3}$ & $(2,81 \pm 0,19) \times 10^{3 * * *}$ \\
\hline Баранина & $(1,19 \pm 0,20) \times 10^{3}$ & $(2,18 \pm 0,22) \times 10^{3 * *}$ \\
\hline Козлятина & $(1,08 \pm 0,18) \times 10^{3}$ & $(1,97 \pm 0,17) \times 10^{3 * * *}$ \\
\hline
\end{tabular}

Примітка: Зберігання м’яса за температури $-12{ }^{\circ} \mathrm{C}:{ }^{1}-$ яловичини на 8 місяць; ${ }^{2}-$ свинини на 3 місяць; ${ }^{3}-$ баранини, козлятини на 6 місяць; * $-\mathrm{P} \leq 0,05 ; * *-\mathrm{P} \leq 0,01 ; * * *-\mathrm{P} \leq 0,001$

Автори стверджують, що санітарно-гігієнічний стан повітря в холодильних камерах на потужностях 3 виробництва і переробки м'яса за зберігання має безпосередній вплив на терміни зберігання м'яса забійних тварин, його безпечність при подальшій реалізації, а також виготовлення 3 нього харчових продуктів (Márcia de Barros et al., 2007). Автором (Salata, 2018) було встановлено, що при зберіганні яловичини за температури $-12{ }^{\circ} \mathrm{C}$ інтенсивність загибелі психротрофної мікрофлори нижча порівняно з температурою зберігання $-20 \ldots-25{ }^{\circ} \mathrm{C}$, а також відмічено, що 3 яловичини зі значним мікробним обсіянням виділяли БГКП і плісеневі гриби.

Варто зазначити, що безпечність та якість м'яса забійних тварин значною мірою залежить від умов зберігання, тобто санітарно-гігієнічного стану холодильних камер і об'єктів потужностей з їх виробництва та обігу (зберігання і реалізації). Одним із етіологічних факторів мікробного псування харчових продуктів при холодильному зберіганні $є$ плісеневі гриби, особливо за температури в холодильниках від $5^{\circ} \mathrm{C}$ до $-9^{\circ} \mathrm{C}$. Ріст плісняви призупиняється або сповільнюється за температури від -4 до $-9{ }^{\circ} \mathrm{C}$, але окремі види плісеневих грибів, наприклад кладоспоріум та тамнідіум, можуть розвиватися за цих температур, при цьому викликаючи зниження якості та псування харчової продукції (Godwin et al., 2007).

Проте необхідно зазначити, що санітарномікробіологічна якість дезінфекції холодильних камер потужностей виробництва та обігу вважається задовільною за умов: якщо проби змивів та відбитків 3 об'єктів площею не менше $20 \mathrm{~m}^{2}$ (столів, стін, поличок, інструментів тощо) за санітарно-показовими показниками (МАФАнМ, колі-титр) мають позитивні результати не більше ніж $10 \%$ від усіх досліджених проб за умови відсутності умовно-патогенних та патогенних мікроорганізмів в усіх дослідних пробах; при вимушеному та повторному контролі якості дезінфекції - повне стовідсоткове дотримання максимально допустимих рівнів мікроорганізмів.

Керуючись Регламентом СС № 2073/2005 (Regulation (EC) №2073/2004), було встановлено гігієнічні критерії технологічного процесу на стадії туш після обробки перед закладанням на заморожування на потужностях з виробництва м'яса забійних тварин у холодильні камери (табл. 4). 


\section{Таблищя 4}

Гігієнічні критерії технологічного процесу для м’яса забійних тварин перед закладкою на холодильне зберігання/реалізацію КУО/ $\mathrm{cm}^{2}, \mathrm{M} \pm \mathrm{m}, \mathrm{n}=9$

\begin{tabular}{|c|c|c|c|c|c|c|}
\hline \multirow{3}{*}{ М'ясо забійних тварин } & \multicolumn{2}{|c|}{$\begin{array}{l}\text { Кількість колоній аеробних } \\
\text { мікроорганізмів }\end{array}$} & \multicolumn{2}{|c|}{ Enterobacteriaceae } & \multicolumn{2}{|c|}{ Salmonella } \\
\hline & \multicolumn{6}{|c|}{ Денний середній логарифм, КУО/см² } \\
\hline & $\mathrm{m}$ & $\mathrm{M}$ & $\mathrm{m}$ & $\mathrm{M}$ & $\mathrm{m}$ & $\mathrm{M}$ \\
\hline \multicolumn{7}{|c|}{$\begin{array}{c}\text { Холодильні камери на потужностях з виробництва м’яса забійних тварин за температури }-12{ }^{\circ} \mathrm{C} \\
\text { та за температури }-2 \ldots-3{ }^{\circ} \mathrm{C}\end{array}$} \\
\hline Яловичина & 2,6 & 4,6 & 1,1 & 1,9 & - & - \\
\hline Свинина & 3,1 & 2,5 & 1,6 & 2,9 & - & - \\
\hline Баранина & 2,4 & 4,1 & 1,2 & 2,0 & - & - \\
\hline Козлятина & 2,5 & 3,9 & 1,3 & 1,8 & - & - \\
\hline \multicolumn{7}{|c|}{$\begin{array}{c}\text { Холодильні камери на оптових базах з виробництва м’яса забійних тварин за температури }-12{ }^{\circ} \mathrm{C} \\
\text { та за температури }-2 \ldots-3{ }^{\circ} \mathrm{C}\end{array}$} \\
\hline Яловичина & 2,7 & 4,2 & 1,2 & 2,0 & - & - \\
\hline Свинина & 2,8 & 4,4 & 1,7 & 2,7 & - & - \\
\hline Баранина & 3,2 & 3,4 & 1,1 & 1,3 & - & - \\
\hline Козлятина & 3,1 & 4,2 & 1,4 & 1,4 & - & - \\
\hline \multicolumn{7}{|c|}{$\begin{array}{c}\text { Холодильні камери у супермаркетах при реалізації м'яса забійних тварин за температури }-6 \ldots-8{ }^{\circ} \mathrm{C} \\
\text { та за температури } 4 \pm 2{ }^{\circ} \mathrm{C}\end{array}$} \\
\hline Яловичина & $2,8 / 3,7$ & $4,1 / 5,2$ & $1,0 / 1,6$ & $2,5 / 2,7$ & - & - \\
\hline Свинина & $3,1 / 3,9$ & $2,5 / 5,4$ & $1,6 / 1,9$ & $2,6 / 3,4$ & - & - \\
\hline Баранина & $2,4 / 3,6$ & $4,1 / 5,5$ & $1,2 / 1,7$ & $2,7 / 2,8$ & - & - \\
\hline Козлятина & $2,5 / 3,7$ & $3,9 / 5,1$ & $1,3 / 2,0$ & $2,7 / 2,5$ & - & - \\
\hline \multicolumn{7}{|c|}{$\begin{array}{c}\text { Холодильні камери/приміщення на агропродовольчих ринках при реалізації м’яса забійних тварин } \\
\text { за температури } 0 \ldots-1{ }^{\circ} \mathrm{C} / \text { за температури } 0 \ldots 6^{\circ} \mathrm{C}\end{array}$} \\
\hline Яловичина & $3,2 / 4,4$ & $5,0 / 5,4$ & $1,1 / 1,5$ & $2,8 / 3,5$ & - & - \\
\hline Свинина & $4,0 / 4,1$ & $4,9 / 5,1$ & $1,6 / 2,3$ & $2,5 / 3,7$ & - & - \\
\hline Баранина & $2,4 / 3,7$ & $4,7 / 5,3$ & $1,2 / 1,7$ & $2,5 / 3,3$ & - & - \\
\hline Козлятина & $2,5 / 3,8$ & $4,9 / 5,2$ & $1,3 / 1,8$ & $2,6 / 3,6$ & - & - \\
\hline
\end{tabular}

Варто зазначити, що денний логарифм по кількості колоній аеробних мікроорганізмів та Enterobacteriaceae у тушах яловичини, свинини баранини, козлятини при реалізації у супермаркетах за температури $4 \pm 2{ }^{\circ} \mathrm{C}$ та на агропродовольчих ринках за температури $0 \ldots 6^{\circ} \mathrm{C}$ перевищував встановлені в Регламенті ЄС № 2073 нормативи, а саме відповідно: за кількістю колоній аеробних мікроорганізмів у м'ясі забійних тварин від $\mathrm{m}=3,6 \log \mathrm{КУО} / \mathrm{cm}^{2}$ до $\mathrm{m}=3,9 \log \mathrm{КУО} / \mathrm{cm}^{2}$ та від $\mathrm{M}=5,1 \mathrm{KУO} / \mathrm{cm}^{2}$ до $\mathrm{M}=5,5 \mathrm{KУO} / \mathrm{cm}^{2}$ (у супермаркетах) та від $\mathrm{m}=3,7 \log \mathrm{KУО} / \mathrm{cm}^{2}$ до $\mathrm{m}=4,4 \log \mathrm{KУО} / \mathrm{cm}^{2}$ та від $\mathrm{M}=5,1 \mathrm{KУO} / \mathrm{cm}^{2}$ до $\mathrm{M}=5,4 \mathrm{KУO} / \mathrm{cm}^{2}$ (на агропродовольчих ринках); Enterobacteriaceae у м'ясі забійних тварин від $\mathrm{m}=1,6 \log \mathrm{KУО} / \mathrm{cm}^{2}$ до $\mathrm{m}=2,0 \log \mathrm{KУО} / \mathrm{cm}^{2}$ та від $\mathrm{M}=2,5 \mathrm{KУO} / \mathrm{cm}^{2}$ до $\mathrm{M}=3,4 \mathrm{KУO} / \mathrm{cm}^{2}$ (у супермаркетах) та від $\mathrm{m}=1,5 \log \mathrm{KУO} / \mathrm{cm}^{2}$ до $\mathrm{m}=2,3 \log \mathrm{KУO} / \mathrm{cm}^{2}$ та від $\mathrm{M}=3,3 \mathrm{KУO} / \mathrm{cm}^{2}$ до $\mathrm{M}=3,7 \mathrm{KУO} / \mathrm{cm}^{2}$ (на агропродовольчих ринках). Гігієнічні критерії технологічного процесу за Salmonella у всіх видів м'яса були відсутні в місцях відбору проби для кожної туші.

Перспективи подальших досліджень в даному напрямі полягають у розробці комплексної системи ризик-орієнтованого контролю санітарно-гігієнічного стану холодильних камер потужностей $з$ виробництва та обігу м'яса забійних тварин.

\section{Висновки}

За температури $-12{ }^{\circ} \mathrm{C}$ та $-2 \ldots-3{ }^{\circ} \mathrm{C}$ із об'єктів холодильних камер на потужності 3 виробництва м'яса забійних тварин та оптовій базі були виділені тест- культури відповідно: Echerichia до 12,5 \% та до $16,7 \%$, а бактерії роду Staphylococcus aureus до $12,5 \%$ (із підлоги і стін) були тільки виділені за температури $-2 \ldots-3{ }^{\circ} \mathrm{C}$. За температури $0 \ldots 6^{\circ} \mathrm{C}$ та $0 \ldots$ $-1{ }^{\circ} \mathrm{C}$ у холодильних камерах із об'єктів на агропродовольчому ринку, ножів та рук працівників найбільша частота виділених культур була встановлена відповідно: бактерій роду Echerichia - до $41,7 \%$ та до 50,0 \%; Salmonella - до 16,7 \% та до 12,5 \%; Staphylococcus aureus - до 33,3 \% та до 29,7 \%; за температури $-6 \ldots-8{ }^{\circ} \mathrm{C}$ та $4 \pm 2{ }^{\circ} \mathrm{C}$ у холодильних камерах супермаркету відповідно: бактерій роду Echerichia - до 16,7 \% та до 50,0 \%; Salmonella - до $12,5 \%$ та до $16,7 \%$; Staphylococcus aureus - до 8,3\% та до 20,8\%;

За температури $4 \pm 2{ }^{\circ} \mathrm{C}$ у холодильній камері супермаркету та за температури $0 \ldots 6^{\circ} \mathrm{C}$ у холодильній камері на агропродовольчому ринку на 2 добу реалізації виявляли прямо пропорційне збільшення обсіменіння поверхні м'яса забійних тварин МАФАнМ відповідно: в яловичині - $(1,15 \pm 0,22) \times 10^{3}$ та $(2,26 \pm 0,21) \times 10^{3} \mathrm{KУO} / \mathrm{cm}^{2} ;$ свинині - $(1,32 \pm 0,18) \times 10^{3}$ та $(2,81 \pm 0,19) \times 10^{3} \quad \mathrm{KУO} / \mathrm{cm}^{2} ; \quad$ баранині $(1,09 \pm 0,20) \times 10^{3}$ та $(2,18 \pm 0,22) \times 10^{3} \mathrm{KУO} / \mathrm{cm}^{2}$; козлятині $-(1,18 \pm 0,12) \times 10^{3}$ та $(1,97 \pm 0,17) \times 10^{3} \mathrm{KУO} / \mathrm{cm}^{2}$.

За зберігання та реалізації яловичини, свинини, баранини і козлятини на потужностях з їх виробництва та обігу за показниками виділених тест-культур бактерій роду Echerichia, Salmonella й Staphylococcus aureus необхідно здійснювати ризик-орієнтований контроль за санітарно-гігієнічним станом об'єктів холодильних камер, ножів, рук працівників, щоб за- 
побігати мікробному обсіменінню м'яса, а також проводити вимушений і повторний контроль якості дезінфекції інспекторами ветеринарної медицини для забезпечення доброго санітарного стану підконтрольних об'єктів.

Гігієнічні критерії технологічного процесу в м'ясі забійних тварин становили за кількістю колоній аеробних мікроорганізмів у м'ясі забійних тварин від $\mathrm{m}=3,6 \log \mathrm{KУО} / \mathrm{cm}^{2}$ до $\mathrm{m}=3,9 \log \mathrm{KУО} / \mathrm{cm}^{2}$ та від $\mathrm{M}=5,1 \mathrm{KУO} / \mathrm{cm}^{2}$ до $\mathrm{M}=5,5 \mathrm{KУO} / \mathrm{cm}^{2}$ (у супермаркетах) та від $\mathrm{m}=3,7 \log \mathrm{KУO} / \mathrm{cm}^{2}$ до $\mathrm{m}=4,4 \log$

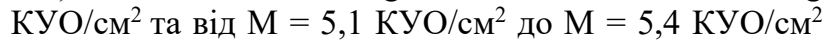
(на агропродовольчих ринках); Enterobacteriaceae у м'ясі забійних тварин від $\mathrm{m}=1,6 \log \mathrm{KУО} / \mathrm{cm}^{2}$ до $\mathrm{m}=2,0 \log \mathrm{KУO} / \mathrm{cm}^{2}$ та від $\mathrm{M}=2,5 \mathrm{KУO} / \mathrm{cm}^{2}$ до $\mathrm{M}=3,4 \mathrm{KУO} / \mathrm{cm}^{2}$ (у супермаркетах) та від $\mathrm{m}=1,5 \mathrm{log}$ $\mathrm{KУO} / \mathrm{cm}^{2}$ до $\mathrm{m}=2,3 \log \mathrm{KУO} / \mathrm{cm}^{2}$ та від $\mathrm{M}=3,3 \mathrm{KУO} / \mathrm{cm}^{2}$ до $\mathrm{M}=3,7 \mathrm{KУO} / \mathrm{cm}^{2}$ (на агропродовольчих ринках).

\section{References}

Bogatko, N. M., \& Sakhniuk, N. I. (2013). The influence of microbial pollution indexes of the air surroundings and walls' sanitary condition of cooling and refrigerate cameras of meat eterpises on safety of slaughter houses' raw materials Bakteriolohichnyi kontrol obiektiv m'iasopererobnoho pidpryiemstva. Naukovyi visnyk LNU veterynarnoi medytsyny ta biotekhnolohii imeni S. Z. Hzhytskoho, 1, 106-109 (in Ukrainian).

Buchanan, R., Coli, M., Lammerding, A. M., \& Clarke, I. R. (1998). Potential Application of Risk Assessment Techniques to Microbiological Issues Related to International Trade in Food and Food Products. Journal of food protection, 61(8), 1075-1086. doi: 10.4315/0362-028x-61.8.1075.

Dwinger, R. H., Golden, T. E., \& Hatakka, M. (2008). Meat Safety and Regulatory Aspects in the European Union. Meat Biotechnology, 2008, 453-465. doi: 10.1007/978-0-387-79382-5 20.

Ercolini, D., Russo, F., Nasi, A., Ferranti, P., \& Villani, F. (2009). Mesofphilic and psychrotrophic bacteria from meat and their spoilage potential in vitro and in beef. Applied and environmental microbiology, 75, 1990 2001. doi: 10.1128/AEM.02762-08.

Esfarjani, F., Khaksar, R., Mohammadi Nasrabadi, F., Roustaee, R., Alikhanian, H., Khalaji, N., \& Hosseini, H. (2016). A preventative approach to promote food safety. British Food Journal, 118(8), 2076-2091. doi: 10.1108/bfj-01-2016-0025.

Garkavenko, T. O., Kaganets, O. O., Timchenko, O. V., \& Cemenchukova, I. V. (2014). Guidelines for sanitary and microbiological control of production and sales facilities that are subject to veterinary supervision. Kiev. DNDI LDVSE.

Godwin, S., Chen, F. C., Chambers, E., \& Coppings, R. (2007). Comprehensive evaluation of temperatures within home refrigerators. Food Protection Trends, 27(3), 168-173. URL: https://agris.fao.org/agrissearch/search.do?recordID=US201300785884.
Macias-Rodriguez, M. E., Navarro-Hidalgo, V., LinaresMorales, J. R., Olea-Rodriguez, M. A., \& VillarruelLopez, A. (2013). Microbiological safety of domestic refrigerators and the dishcioths used to clean them in Guadalajara, Jalisco, Mexico. Journal of food protection, 76(6), 984-990. doi: 10.4315/0362-028X.JFP$12-258$.

Márcia de Barros, A. F., Nero, L. A., Monteiro, A. A., \& Beloti, V. (2007). Identification of main contamination points by hygiene indicator microorganisms in beef processing plants. Food Science and Technology, 27(4), 856-862. doi: 10.1590/S0101-20612007000400028.

Milios, K., Drosionos, E., \& Zoiopoulos, P. (2012).Factors influencing HACCP implementation in the food industry. Journal of Hellenic Veterinary Medical Society, 63, 283-290. doi: 10.12681/jhvms.15442.

Nagibina, V. V., Rebezov, M. B., \& Anokhina, E. S., (2014). Sanitary and hygienic measures in the meat processing industry. Scientific researches and their practical application. Modern state and ways of development. SWorld, 112 October. URL: www.sworld.com.ua.

Odewade, J. O., Oyelami, L. O., \& Fasogbon, A. O. (2018). Microbial analisis of processed foods stored in domestic refrigerators of selected in Ile-Ife, Osun State, Nigeria. American Journal of Bioscience and Bioengineering, 6(3), 21-26. doi: 10.11648/J.bio.20180603.11.

Paliy, A. P., Rodionova, K. O., Braginec, M. V., Paliy, A. P., \& Nalivayko, L. I. (2018). Sanitary-hygienic evaluation of meat processing enterprises productions and their sanation. Ukrainian Journal of Ecology, 8(2), 8188. doi: $10.15421 / 2018313$.

Regulation (EC) of the European Parliament and of the Council on 28.01.2002 №178/2002, laying down the general principles and requirements of food law, establishing the European Food Safety Authority and laying down procedures i matters of food safety. URL: https://eur-lex.europa.eu/legal-content/EN/ALL/ ?uri=CELEX\%3A32002R0178.

Regulation (EC) of the European Parliament and of the Council on 29.04.2004 №852/2004. On the hygiene of foods tuffs. URL: https://eur-lex.europa.eu/legalcontent/EN/TXT/?uri=CELEX\%3A32004R0852.

Regulation (EC) of the European Parliament and of the Council on 15.11.2005 №2073/2004. Pro mikrobiolohichni kryterii dlia kharchovykh produktiv. URL: https://eur-lex.europa.eu/legal-content/EN/ALL/ ?uri $=$ CELEX\%3A32005R2073.

Rodionova, K., Steshenko, V., \& Yatsenko, I. (2020). Approximating Ukraine's laws to those of the European Union concerning meat and meat products cold chain. Journal of Advanced Research in Law and Economic, 9(3), 978-992. doi: 10.14505/jarle.v11.3(49).34.

Salata, V. Z. (2018). Dynamics of the genetic composition of psychrotrophic microflora of frozen beef in the process of storage. Problemy zooinzhenernoi ta veterynarnoi medytsyny: zbirnyk naukovykh prats KhDZVA, 3(2), 93-97 (in Ukrainian).

Schillinger, U., \& Lucke, F. (2003). Hygiene control of the meat fresh in reservoirs. Food microbiology, 4(2), 199-208. 
Velemets, N. (2020). Yaki vymohy vysuvaie BRC Food ta komu mozhe znadobytysia sertyfikatsiia za tsym mizhnarodnym standartom. Upravlinnia yakistiu, 6. URL: https://techmedia.com.ua/node/2549 (in Ukrainian).
Ichakova, O. I. (2011). Bakteriolohichnyi kontrol obiektiv m'iasopererobnoho pidpryiemstva. Naukovyi visnyk LNU veterynarnoi medytsyny ta biotekhnolohii imeni S. Z. Hzhytskoho, 14, 4(50), 239-242 (in Ukrainian). 